\title{
Gerakan Literasi Dalam Meningkatkan Minat Baca Masyarakat Melalui Peran Perpustakaan dan Pustakawan
}

\author{
Fepi Febianti \\ Universitas Sebelas April \\ E-mail: fepifebianti@gmail.com
}

Received: 24-12-2021

Revised: 28-12-2021

Accepted: 30-12-2021

DOI: $10.24036 /$ ib.v3i1.268

\begin{abstract}
Interest in reading is the emergence of feelings of pleasure or strong interest that encourages individuals to carry out activities so that they do it on their own accord. Then there are attempts to do this activity repeatedly. reading is an important activity. Human civilization will not be far from this activity. Even in its history, a civilization is said to be advanced if humans at that time had the ability to read and write. Even in Islam, the first commandment to the Prophet Muhammad was to read (iqra: read). It has also been proven, a nation with a high interest in reading becomes a nation that excels in science and technology. By reading, you can find a variety of knowledge and make discoveries in both the scientific and social fields. Based on research on reading interest, broadly speaking, there are two factors, namely internal and external factors. Internal factors generally include perceptions, motivations, and individual feelings towards reading activities. Meanwhile, external factors relate to the environment, ease of access to books, availability of facilities and infrastructure, technological developments, and even distribution of reading books. Therefore, a unique literacy is needed to support the reading culture of the community. Literacy has an important role in the life of a learning community that lives in an era that is based on current knowledge, technology, and information. Human civilization can be awakened by mastery of literacy based on reading, writing, and critical thinking activities. Literacy is a process of how a person communicates in society. In addition, literacy can also be interpreted as practice and social relations related to knowledge, language, and culture. Libraries with librarians can be used to develop a literacy culture for users in particular and society in general. With the available resources, together with stakeholders and community groups, they can innovate, create, and vary literacy-based library services. Thus the literacy culture will grow and develop.
\end{abstract}

Keywords: Literacy, reading interest, library, librarian.

\begin{abstract}
Abstrak
Minat baca merupakan munculnya perasaan senang atau ketertarikan kuat yang mendorong individu untuk melakukan kegiatan membaca sehingga ia melakukannya atas kemauan sendiri.Kemudian ada upaya untuk melakukan kegiatan ini secara berulang. membaca merupakan kegiatan penting. Peradaban manusia tidak akan jauh-jauh dari kegiatan ini. Bahkan dalam sejarahnya, sebuah peradaban dikatakan maju apabila manusia-manusia pada masa tersebut telah memiliki kemampuan membaca dan menulis. Dalam ajaran Islam pun, perintah pertama kepada Nabi Muhammad adalah membaca (iqra: bacalah). Telah terbukti juga, bangsa dengan minat baca tinggi menjadi bangsa yang unggul dalam ilmu pengetahuan dan teknologi. Dengan membaca, kalian bisa menemukan beragam pengetahuan dan membuat penemuan baik di bidang saintek maupun sosial. Berdasarkan penelitian tentang minat baca, secara garis besar ada dua faktor yaitu faktor internal dan faktor eksternal.Faktor internal umumnya mencakup persepsi, motivasi, dan perasaan individu terhadap aktivitas membaca. Sementara faktor eksternal berhubungan dengan lingkungan, kemudahaan akses mendapatkan buku, ketersediaan sarana dan prasarana, perkembangan teknologi, hingga distribusi buku bacaan yang merata. Oleh karena itu dibutuhkan sebuah Literasi yang unik untuk mendukung budaya baca masyarakat. Literasi mempunyai
\end{abstract}


107

Published by Program Studi Perpustakaan dan Ilmu Informasi

FBS Universitas Negeri Padang, Indonesia

peran penting dalam kehidupan masyarakat pembelajar yang hidup di era yang mengedepankan pengetahuan, teknologi, dan informasi saat ini. Peradaban manusia dapat terbangun karena penguasaan literasi yang berbasis pada kegiatan membaca, menulis, dan berpikir kritis. Literasi sebagai suatu proses bagaimana seseorang berkomunikasi dalam masyarakat. Selain itu, literasi juga dapat dimaknai sebagai praktik dan hubungan sosial yang terkait dengan pengetahuan, bahasa, dan budaya. Perpustakaan dengan pustakawannya dapat memaknai perannya untuk menumbuhkembangkan budaya literasi bagi pemustaka khususnya dan masyarakat pada umumnya. Dengan sumber daya yang dimiliki, bersama stakeholder dan kelompok masyarakat dapat melakukan inovasi, kreasi, variasi layanan perpustakaan yang berbasis literasi diharapkan mampu menumbuhkembangkan minat baca dan tulis sehingga kemampuan literasi masyarakat semakin meningkat. Dengan demikian budaya literasi pun akan semakin tumbuh dan berkembang.

Kata kunci: Literasi, minat baca, perpustakaan, pustakawan.

\section{PENDAHULUAN}

Setiap tanggal 17 Mei, Indonesia memperingati Hari Buku Nasional. Penetapan Hari Buku Nasional berlaku sejak tahun 2002 oleh Menteri Pendidikan Indonesia saat itu, Abdul Malik Fadjar. Hari Buku Nasional yang ditetapkan pada 2002 lalu bersamaan dengan perayaan 22 tahun Perpustakaan Nasional (Perpusnas). Perpustakaan Nasional Republik Indonesia sendiri didirikan pada $17 \mathrm{Mei}$ 1980. Selain itu, penetapan Hari Buku Nasional juga memiliki tujuan untuk meningkatkan minat baca. Saat itu, minat baca di Indonesia masih rendah, yaitu rata-ratanya hanya sekitar 18.000 judul buku per tahun. Jumlah ini masih rendah jika dibandingkan dengan
Tiongkok yang memiliki minat baca rata-rata 140.000 judul buku per tahun.

Penelitian UNESCO pada 2016 menunjukkan, kebiasaan membaca di Indonesia tergolong sangat rendah. Hasil studi berjudul "The World's Most Literate Nations" menyebutkan, Indonesia berada di peringkat ke-60 dari 61 negara. Selain itu, berdasarkan survei PISA yang dirilis OECD pada tahun 2019, tingkat literasi Indonesia berada di peringkat 10 terbawah dari 70 negara. Rendahnya budaya literasi di Indonesia menjadi tantangan yang perlu disikapi dari tahun ke tahun. Keterbatasan akses terhadap sumber bacaan kerap jadi masalah dalam meningkatkan tingkat literasi di Indonesia. 
Peneliti di Pusat Penelitian Kebijakan Pendidikan dan Kebudayaan Balitbang Kemendikbud, Lukman Solihin, mengatakan keterbatasan akses ini bisa diatasi misalnya dengan memanfaatkan teknologi internet, gadget, serta perangkat elektronik lain.Dengan begitu, diharapkan masalah keterbatasan akses bisa dikurangi dan penyebaran buku lebih merata sehingga mampu menumbuhkan minat dan kebiasaan membaca. Organization for Economic Cooperation and Development (OECD) juga pernah melansir hasil survei yang menunjukkan, kemampuan membaca, berhitung, dan pengetahuan sains anak-anak Indonesia masih di bawah negaranegara tetangga seperti Singapura, Malaysia, Vietnam dan Thailand, dan sejajar dengan negara-negara miskin di Afrika. Data ini berdasarkan hasil tes The Programme International Student Assessment (PISA). Bukan hanya anakanak, indeks membaca dan tingkat literasi orang dewasa, menurut OECD, juga jeblok seperti ditunjukkan dari hasil tes The Programme for International Assessment of Adult Competencies, sebuah tes kompetensi sukarela untuk orang dewasa. Bahkan dari 40 negara yang diuji, Indonesia berada di posisi paling buntut.

Menurut World Economic Forum, tingkat literasi dasar yang perlu dikuasai oleh orang dewasa meliputi kemampuan baca-tulis, literasi numerasi atau berhitung, literasi finansial (keuangan), literasi sains, literasi budaya dan kewarganegaraan, serta literasi informasi teknologi dan komunikasi atau digital. Mengutip pernyataan Muhammad Syarif Bando, Kepala Perpustakaan Nasional, di Majalah Gatra bahwa berdasarkan hasil riset Perpusnas pada tahun 2017, frekuensi membaca orang Indonesia rata-rata 3-4 kali per minggu, dengan lama waktu membaca per hari hanya 30-59 menit. Jumlah buku yang dibaca per tahun 5-9 buku, sehingga diperoleh rata-rata tingkat kegemaran membaca masyarakat Indonesia 36,48. Berdasar pada data tersebut, jelas masalah 
Published by Program Studi Perpustakaan dan Ilmu Informasi FBS Universitas Negeri Padang, Indonesia

budaya literasi menjadi masalah yang kritis bagi bangsa kita, yang harus segera mendapat Tindakan nyata untuk mengatasinya. Salah satu sarana yang ikut bertanggung jawab terhadap peningkatan budaya literasi adalah perpustakaan.

Pustakawan sebagai pengelola perpustakaan harus dapat memaknai fungsi perpustakaan sebagai wahana pendidikan, penelitian, pelestarian, informasi, dan rekreasi untuk meningkatkan kecerdasan dan keberdayaan bangsa sesuai dengan pasal 3 UU Nomor 43 Tahun 2007 untuk menumbuhkembangkan budaya literasi. Budaya Literasi belum mengakar kuat dalam budaya bangsa kita. Masyarakat lebih sering menonton atau mendengar dibandingkan membaca apalagi menulis. Pemecahan masalah rendahnya budaya literasi tidak hanya menjadi tanggung pemerintah saja tetapi seluruh elemen bangsa termasuk perpustakaan dan pustakawan. Berangkat dari upaya menumbuhkembangkan budaya literasi masyarakat, idealnya perpustakaan dan pustakawan dapat mengikuti perkembangan kebudayaan dan pengetahuan dan teknologi informasi yang sedang terjadi. Perpustakaan harus mengambil peran tidak hanya sebagai penyedia informasi tetapi bagaimana memaknai perannya yang lebih luas lagi agar budaya literasi dapat tumbuh dan berkembang. Sesuatu yang menjadi permasalahan di sini adalah pemaknaan peran perpustakaan dan pustakawan seperti apa agar dapat menumbuhkembangkan budaya literasi tersebut.

$\begin{array}{cc}\text { Meningkatnya } & \text { kesadaran } \\ \text { masyarakat terhadap pentingnya }\end{array}$
literasi informasi sebagai suatu tuntutan keterampilan hidup (life skill) di era informasi tidak akan berarti jika hal itu tidak diimbangi oleh kemampuan masyarakat sendiri dalam mengakses informasi yang dibutuhkan. Bagi sebagian kecil masyarakat, kehadiran teknologi informasi dan komunikasi memang telah memudahkan mereka dalam mengakses informasi khususnya melalui jaringan internet. Akan tetapi, 


\section{Info Bibliotheca}

Jurnal Perpustakaan dan Ilmu Informasi

107

Published by Program Studi Perpustakaan dan Ilmu Informasi

FBS Universitas Negeri Padang, Indonesia

bagi sebagian besar lainnya mendapatkan akses informasi nampaknya masih menjadi suatu kemewahan karena sebagian besar mereka belum tersentuh sama sekali oleh kemajuan teknologi tersebut. Fenomena ketimpangan dalam mengakses informasi ini kini telah menjadi salah-satu isu global yang dikenal dengan istilah pembelahan digital (digital divide). Harapan awalnya, ketika internet diperkenalkan kepada masyarakat sekitar satu dekade lalu, teknologi ini dapat memberikan kemudahan akses informasi kepada seluruh lapisan masyarakat. Namun dalam perkembangannya, harapan tersebut terkesan berlebihan, karena dalam kenyataannya teknologi ini hanya dapat dinikmati oleh segelintir elite. Sebagai gambaran, pada tahun 2003 lalu hanya tujuh persen dari 6,4 milyar penduduk dunia yang memiliki akses ke web (NielsenNet Rating, August 2003).

Masyarakat pengakses internet juga masih terkonsentrasi di kawasan Amerika Utara, Eropa dan Asia Pasifik, sementara di belahan dunia lainnya terutama di kawasan Afrika, pedesaan India dan wilayah Asia Selatan dan Tenggara aksesnya masih relatif terbatas. Akibatnya, peluang bangsabangsa yang lebih miskin untuk mendapatkan manfaat dari internet menjadi sangat terbatas pula. Di Dunia Ketiga, biaya untuk pengadaan peralatan/fasilitas teknologi informasi umumnya masih jauh dari jangkauan masyarakat, karena pemenuhan kebutuhan untuk itu harus bersaing dengan kebutuhan sumberdaya untuk bertahan hidup. Sebagai negara berkembang, Indonesia termasuk negara yang tidak diuntungkan dalam fenomena ketimpangan digital tersebut. Seperti negara berkembang lainnya, ada beberapa faktor yang menyebabkan ketimpangan digital masih menghinggapi sebagian besar masyarakat Indonesia, antara lain, standar pendidikan yang relatif rendah, masih tingginya angka buta aksara, minimnya budaya baca dan lebih dominannya tradisi lisan, hambatan bahasa, persaingan ketat untuk 
107

Published by Program Studi Perpustakaan dan Ilmu Informasi

FBS Universitas Negeri Padang, Indonesia

mendapatkan anggaran pembangunan yang relatif terbatas, kurangnya staf professional dan teknis yang terampil, serta pasokan listrik yang tidak stabil.

Di tengah fenomena ketimpangan digital seperti itu, institusi perpustakaan sebenarnya berpeluang besar untuk memainkan peran sebagai jembatan dalam mengatasi ketimpangan yang ada, karena institusi ini pada dasarnya dibangun untuk melayani kepentingan seluruh masyarakat. Agar institusi perpustakaan dapat menjadi basis bagi berkembangnya masyarakat informasi, maka para pengelola perpustakaan selayaknya mengkaji kembali azas-azas pelayanannya. Dalam hal ini, gagasan yang dikemukakan oleh Craeford dan Gorman seperti dikutip oleh Awcock tentang beberapa prinsip atau asas baru untuk perpustakaan nampaknya layak untuk dipertimbangkan. Menurut kedua tokoh, perpustakaan seharusnya dikelola dengan lima prinsip, yaitu: (1) Perpustakaan melayani seluruh umat manusia; (2) Menghargai semua bentuk pengetahuan dikomunikasikan;
Gunakan teknologi secara tepat untuk meningkatkan pelayanan; (4) Lindungi akses bebas terhadap pengetahuan; dan (5) Hormati masa lalu dan ciptakan masa depan.

Perpustakaan terutama perpustakaan umum harus terbuka bagi semua kalangan masyarakat tanpa membeda-bedakan latar belakangnya. Kaya dan miskin, tua dan muda, profesional dan pengangguran, kulit berwarna dan putih, pebisnis dan keluarga, terpelajar dan sekedar hobby, dan sebagainya dapat memanfaatkan fasilitas perpustakaan yang tersedia. Bahkan di negara lain, banyak anggota masyarakat miskin dan tidak berpunya mencari tempat yang nyaman untuk sekedar berlindung dari cuaca dingin dan hujan dengan duduk dan membaca surat kabar di dalam perpustakaan. Warga masyarakat yang sedang kebingungan melakukan apa pada harihari yang sulit, pergi ke perpustakaan untuk membaca sambil bersantai, dan mungkin secara tidak sengaja 
107

Published by Program Studi Perpustakaan dan Ilmu Informasi

FBS Universitas Negeri Padang, Indonesia

mendapatkan gagasan baru untuk melakukan sesuatu yang bermanfaat.

Warga masyarakat dari berbagai etnis yang tidak memiliki latar belakang pengetahuan yang memadai tentang lingkungan tempat tinggalnya dan para wisatawan domestik dari mancanegara yang masih asing terhadap kota atau daerah yang didatanginya, pergi ke perpustakaan umum untuk mendapatkan berbagai informasi yang mereka perlukan. Anggota masyarakat penyandang cacat fisik dapat memanfaatkan perpustakaan umum untuk mendapatkan berbagai informasi yang berguna untuk menambah semangat dan kualitas hidup mereka.

Perpustakaan harus memelihara dan menjaga dengan baik berbagai jenis koleksinya mulai dari bahan stensilan sampai dengan multi-media dalam bentuk elektronik atau digital. Berbagai jenis rekaman pengetahuan tersebut dikoleksi dan bahkan dilindungi dengan undang-undang deposit untuk melindungi hasil budaya lokal maupun nasional sepanjang masa.
Memang di era digital saat ini, perpustakaan harus berpacu untuk mengumpulkan bahan-bahan yang terekam dalam bentuk digital seperti $\mathrm{CD}$, dan multimedia lailnnya, namun perpustakaan juga tetap harus memelihara rekaman pengetahuan dalam bentuk kertas dan yang lainnya untuk keperluan yang akan datang.

Penggunaan teknologi terutama teknologi informasi di perpustakaan bukan sesuatu yang baru lagi. Tetapi pemanfaatan teknologi ini pada beberapa perpustakaan terutama di Indonesia nampaknya masih sangat lambat. Teknologi komputer telah banyak digunakan untuk menangani kegiatan rutinitas kerumahtanggaan perpustakaan (library housekeeping) yang mencakup bidang pengadaan, pengatalogan, pengawasan sirkulasi, pengawasan serial dan penyediaan katalog online untuk umum. Pemanfaatan teknologi ini diakui mampu meningkatkan efisiensi pengelolaan perpustakaan dan selanjutnya memberikan kemudahan dan efisiensi bagi pengguna 
perpustakaan. Disamping itu, pemanfaatan teknologi informasi untuk remote access dan penggunaan bahanbahan digital yang semakin banyak dikoleksi oleh perpustakaan juga semakin penting. Penyediaan bahanbahan referens dalam bentuk CD multimedia dan bahan-bahan interaktif dan tutorial lainnya mengharuskan perpustakaan untuk menyediakan sejumlah komputer dan peralatan lainnya serta prasarana jaringan baik lokal maupun global untuk pendukungnya.

Di negara-negara maju timbul perdebatan tentang apakah pelayanan perpustakaan bisa tetap diberikan secara gratis atau beberapa pelayanan akan dikenakan biaya seperti pelayanan yang menggunakan teknologi komputer. Di Indonesia, sejauh ini pada dasarnya pelayanan perpustakaan umum adalah gratis, meskipun timbul pertanyaan tentang kemungkinan mengutip pembayaran untuk beberapa jenis pelayanan karena terbatasnya pendanaan dari pemerintah. Diharapkan dengan pengutipan biaya tersebut, perpustakaan mampu memperkenalkan beberapa pelayanan baru yang sebelumnya belum bisa diselenggarakan.

Marilyn Mason dalam artikelnya yang diterbitkan dalam Library Journal baru-baru ini mengingatkan bahwa sebaiknya perpustakaan dan pemerintah yang demokratis harus selalu bergandengan-tangan untuk memberikan pelayanan dengan prinsip persamaan kepada semua anggota masyarakat. Jika beberapa pelayanan dikutip pembayaran, kemungkinan besar anggota masyarakat dari kalangan miskin dan tidak berpunya tidak mempunyai akses yang sama terhadap sebahagian pelayanan perpustakaan. Penggunaan internet pun harus dipikirkan apakah akan dikenakan pembayaran karena bila hal itu dilakukan maka persamaan hak (equity) terhadap akses pengetahuan tidak bisa berjalan. Dalam hal tertentu dimana pengguna tidak melakukan sendiri penelusuran, tetapi meminta pustakawan untuk melakukannya 
untuk mereka (seperti peneliti dan pebisnis), kemungkinan pengutipan biaya dapat dilakukan.

Prinsip ini merupakan tantangan dan sekaligus peluang terbesar bagi dunia perpustakaan. Perpustakaan memiliki tugas publik untuk melindungi atau memelihara bukti-bukti dokumenter dari peradaban, karena tanpa sumber rekaman masa lalu, ilmu pengetahuan dan pembelajaran modern tidak akan pernah ada dan riset dalam beberapa disiplin tidak mungkin dilakukan. Pelajaran sejarah tidak akan dipelajari dan pengabaian ini akan berlaku dalam setiap bidang usaha manusia. Perpustakaan memegang peranan penting, walaupun sering diabaikan, dalam memberikan sumbangan pada pengembangan masyarakat kita Undang-undang deposit seharusnya melindungi berbagai koleksi termasuk pengetahuan-pengetahuan lokal/tradisional yang hidup dalam masyarakat Indonesia. Koleksi seperti itu merupakan bukti pentingnya masa lalu seperti halnya masa sekarang dan bahkan untuk memprediksi masa yang akan datang. Meskipun ada yang meramalkan penghapusan perpustakaan berkaitan dengan perkembangan dunia elektronik yang dapat diakses oleh setiap orang dari mana saja dan kapan saja, tetapi banyak yang tidak mempercayainya. Pustakawan publik harus berbicara dengan bangga tentang suatu masa depan yang memikat dengan perpustakaan tetap dihati masyarakatnya. Karenanya, perpustakaan harus tetap berdiri tegar sebagai simbol pentingnya pengetahun dan pembelajaran.

Abad sekarang dikenal orang dengan Abad 21 atau millenium ke tiga, abad informasi, era keterbukaan, era globalisasi ataupun era teknologi informasi. Menurut Zuntriana, Perkembangan TIK, terutama teknologi internet generasi ke 2 (web.2.0) memaksa pustakawan untuk mulai beralih paradigma dan melakukan reposisi terhadap perannya selama ini. Berbagai perubahan yang dibawa oleh library 2.0 mensyaratkan adanya 
107

Published by Program Studi Perpustakaan dan Ilmu Informasi

FBS Universitas Negeri Padang, Indonesia

transformasi dalam diri pustakawan, berupa peningkatan kapasitas, kompetensi, kecerdasan, dan perbaikan sikap.Librarian 2.0 harus memiliki kemauan untuk berbagi, bersahabat, bergaul, mahir menulis, dan aktif dalam berbagai jejaring sosial. Disamping pustakawan 2.0 adalah pustakawan yang dapat bergerak aktif membangun kemampuan literasi pengguna, baik di dunia nyata maupun maya, bersikap pro aktif, dan mampu melakukan transfer pengetahuan. Selanjutnya untuk menjadi Librarian 2.0, ada persyaratan-persyaratan (Abram dalam Zuntriana), antara lain: 1. Memahami benar-benar berbagai manfaat yang ditawarkan oleh web 2.0, 2. Mau mempelajari alat dan perangkat utama web 2.0 dan Library 2.0, 3. Mampu memadukan formt koleksi digital dan tercetak, 4. Mampu mengakses informasi dalam berbagai format, 5 . Mampu menggunakan informasi non tekstual, seperti gambar, suara, citra bergerak, 6. Menggunakan dan mengembangkan jejaring sosial untuk memperoleh manfaat maksimal, 7 .
Mampu berkomunikasi dengan orang lain melalui beragam teknologi, seperti telepon, skype, IM, SMS, texting, email, referensi virtual, dlsb. Terkait dengan peran pustakawan dalam pembangunan teknologi informasi dan komunikasi, Menteri Komunikasi dan Informatika RI dalam Hak mengemukakan: 1. Pustakawan sebagai "agent of change" dalam masyarakat, selain memiliki kewajiban profesional, juga menerima panggilan moral untuk melakukan percepatan proses pembelajaran masyarakat. 2 . Pustakawan sebagai profesi yang mengabdi kepada kedua kepentingan, yakni warga masyarakat, umat manusia secara umum dan lembaga tempat bekerja, dimana mereka berkewajiban memelihara keseimbangan dan keserasian tugas bagi kemaslahatan umat. 3. Pustakawan sebagai anggota masyarakat yang memiliki posisi sosial tersendiri yang bersifat khas dan unik, maka mereka diharapkan juga memerankan diri sebagai tokoh informasi dalam pembangunan masyarakat yang lebih dipahami 
Published by Program Studi Perpustakaan dan Ilmu Informasi FBS Universitas Negeri Padang, Indonesia

sebagai upaya pemberdayaan masyarakat.

Dari peran pustakawan di atas dapat disimpulkan bahwa seorang pustakawan di er teknologi informasi harus bisa menjadi agen perubahan bagi diri dan masyarakat, serta bisa menempatkan dirinya sebagai manajer informasi bagi masyarakat. Dalam menyikapi perubahan yang terjadi, ada beberapa hal yang harus diperhatikan, yakni: 1. Berani menerapkan konsep pemecahan masalah secara sistematis. 2. Berani bereksperimentasi 3 . Belajar dari pengalaman diri sendiri 4. Transfer informasi dan pengetahuan 5 . Keterlibatan seluruh karyawan. Bila 5 hal tersebut dikaitkan dengan organisasi perpustakaan, maka yang perlu diperhatikan adalah yang pertama perpustakaan harus mempunyai konsep yang sistematis dalam menghadapi setiap permasalahan. Jangan biarkan permasalahan menumpuk tanpa suatu solusi. Pimpinan perpustakaanharus berani mengajak staf perpustakaan untuk memecahkan permasalahan. Perpustakaan harus berani berinovasi, mencoba konsep-konsep baru yang inovatif, jangan takut gagal. Karena kesalahan yang produktif lebih baik daripada keberhasilan yang tidak produktif.

$$
\text { Pengalaman }
$$

tersebut dijadikan perpustakaan untuk belajar dari pengalaman diri sendiri. Dari pengalaman yang di dapat dilakukan evaluasi-evaluasi. Kemudian hasilnya disharekan kepada staf perpustakaan sebagai bentuk transfer informasi dan pengetahuan. Sehingga setiap perubahan yang terjadi merupakan suatu usaha bersama dari pimpinan dan staf perpustakaan. Bila 5 hal tersebut dapat dijalankan diperpustakaan, tentunya tidak akan menimbulkan reaksi yang tidak diinginkan, seperti: keengganan berubah, kurangnya pemahaman mengenai alasan mengapa harus melakukan perubahan, adanya bias organisasi menyangkut kegiatankegiatan atau orang-orang tertentu, dan ketakutan terhadap sesuatu yang tidak 
diketahui. Sedangkan untuk melakukan perubahan dalam organisasi dibutuhkan suatu metode yang spesifik, seperti: 1. Mengubah mindset melalui pelatihan-pelatihan achievement motivation, team building, ketrampilanketrampilan human relations, dan lainlain. 2. Menggunakan sekelompok kader yang menjadi agen perubahan. 3 . Mendayagunakan teknologi untuk mencapai keunggulan kompetitif. Ke tiga metode tersebut bila dikaitkan dengan organisasi perpustakaan, maka perpustakaan harus siap menghadapi setiap perubahan untuk kemajuan perpustakaan, karena perubahan yang dilakukan semata-mata untuk memenuhi kebutuhan informasi pemustaka yang juga selalu berkembang seiring dengan perkembangan zaman.

\section{METODE}

Metode pengumpulan data yang digunakan adalah kajian kepustakaan, yaitu teknik mengumpulkan data yang diambil dari kepustakaan (buku, dokumen, artikel, laporan, web atau internet). Data juga diperoleh dari pengalaman penulis dalam kegiatan perpustakaan yang berbasis pada literasi dan melakukan sesi wawancara dengan beberapa pustakawan yang temui dilapangan.

\section{HASIL DAN PEMBAHASAN}

Perpustakaan sebagai institusi yang berfungsi sebagai wahana pendidikan, penelitian, pelestarian, informasi, dan rekreasi seperti yang diamanahkan oleh Undang-Undang Nomor 43 Tahun 2007 tentang Perpustakaan, harus mempelopori gerakan literasi yang massif yakni gerakan membaca dan menulis yang diimbangi dengan membangun kerangka berpikir kritis dan logis sehingga akan menumbuhkembangkan budaya literasi pada masyarakat umumnya dan pemustaka pada khususnya. Membahas masalah literasi akan lebih menarik, jika terlebih dahulu merenungkan kembali "Catatan Najwa” yang dibaca pada akhir acara "Mata Najwa" di salah satu stasiun TV swasta. Adapun Catatan 
Najwa : "Tak sekadar membaca, Jika melek aksara telah menjadi hal biasa, Minat baca adalah hal yang istimewa, Sekadar mengeja telah menjadi kebiasaan, Namun gemar membaca adalah keistimewaan, Meningkatkan minat baca memang tak gampang, Berbagai kendala banyak menghadang, Budaya menonton kian merajalela. Sosial media lebih menggoda ketimbang pustaka, Bukubuku memang terus diproduksi, Tapi tak serta merta meningkatkan literasi, Belum lagi persoalan distribusi, BukuBuku sulit diakses mereka yang terisolasi, Perpustakaan hanya diisi diktat dan kisi-kisi, Sedikit yang bisa menghidupkan imajinasi. Terpujilah mereka yang gigih sebarkan bahan bacaan kepada mereka yang haus ilmu pengetahuan. Merekalah yang meyodorkan jendela dunia agar anakanak bangsa dapat berpikir seluas cakrawala, agar kita menjadi negara yang maju, menjadi bangsa yang melahirkan para penemu. Dengan catatan di atas, maka sebuah perpustakaan harus mampu memaknai literasi sebagai sebuah proses menciptakan karya yang didahului dengan pembiasaan menulis, membaca serta bepikir. Melalui karya itulah akhirnya dapat mempengaruhi orang lain untuk berpikir ulang serta mengolahnya lagi sehingga dapat tercipta karya baru lagi, begitu seterusnya sehingga tercipta budaya literasi.

Tingkat literasi suatu daerah dapat menunjukkan keberhasilan pendidikan yang diselenggarakan. Literasi merupakan upaya pembangunan manusia. Membangun manusia berarti membangun karakter dari suatu bangsa. Kemajuan dan keberhasilan setiap aspek kehidupan lahir dari bangsa yang terpelajar dan terdidik sehingga terus mengalami perkembangan kearah yang lebih baik. Salah satu bentuk nyata gerakan masyarakat berbasis literasi di Kabupaten Sumedang, yaitu adanya sebuah Forum Literasi Sumedang. Sebuah forum yang menghimpun orang-orang yang peduli akan keberaksaraan di Sumedang. Menurut 
Alamsyah (2017), literasi merupakan upaya pembangunan manusia, dan tidak menutup kemungkinan Sumedang bisa menjadi Kota Literasi dimasa depan nanti. Anggota yang tergabung dalam forum bermacam-macam, diantaranya ada perpustakaan, media sumedang, organisasi kepemudaan, taman baca, komunitas hingga lembaga pendidikan.

Di Kabupaten Sumedang, gerakan literasi mulai diperhatikan kembali mengikuti isu gerakan literasi yang berkembang di Nasional dari Kementerian Pendidikan dan Kebudayaan (Kemendikbud) sejak 2016. Dengan hadirnya beberapa komunitas penggiat dan peduli akan literasi di Sumedang yang terhimpun dalam sebuah Forum Literasi Sumedang menjadi titik awal bangkitnya kembali literasi di Kabupaten Sumedang. FLS sebagai katalisator gerakan masyarakat berbasis literasi di Sumedang. Menurut National Institute of Literacy dalam Jabarprov (2016), bahwa literasi adalah kemampuan individu untuk membaca, menulis, berbicara, menghitung, dan memecahkan masalah pada tingkat keahlian yang diperlukan dalam pekerjaan, keluarga dan masyarakat.

Masyarakat yang tergabung dengan FLS terhitung sebanyak 52 orang di grup online FLS. Forum Literasi Sumedang didirikan pada hari Sabtu 29 April 2017 secara resmi di Gedung Negara Kabupaten Sumedang. Pada awal pembentukannya, FLS sudah giat menyelenggarakan kegiatankegiatan literasi seperti seminar motivasi, gerakan baca buku gratis dan workshop kepenulisan. Hal ini terlihat dari media sosial FLS seperti instagram (@forumliterasisumedang), grup WhatsApp Forum Literasi Sumedang, serta pemberitaan- pemberitaan di media online maupun tercetak di Kabupaten Sumedang. Kebutuhan akan gerakan- gerakan literasi di Kabupaten Sumedang ini ditunjukkan dengan kondisi bahwa angka melek huruf tahun 1996-2013, usia lebih dari 15 tahun di Kabupaten Sumedang mengalami peningkatan dari tahun ke 
tahun (BPS, 2015). Tercatat hingga tahun 2013, angka melek huruf mencapai 98,23 \%. Maka dapat dikatakan bahwa generasi muda di Kabupaten Sumedang hampir dominan dapat membaca. Suatu modal untuk dapat menanamkan kebiasaan membaca sebagai pondasi literasi. Bahkan di Jawa barat, menurut data Badan Statistik tahun 2015-2016, persentase masyarakat yang buta huruf usia produktif (15-44 tahun) mengalami penuruan sekitar $0,6 \%$ dari $0,29 \%$ ke $0,23 \%$. Hal tersebut menunjukkan bahwa di Jawa Barat, pemerintah provinsi maupun pemerintah daerah, sadar akan pentingnya kemampuan membaca dan literasi. Sebelum pada tahap budaya membaca, kemudian juga perlu diperhatikan mengenai minat baca.

Liliawati dalam Sandjaja (2005) mengartikan minat baca adalah suatu perhatian yang kuat dan mendalam disertai dengan perasaan senang tarhadap kegiaan membaca sehingga dapat menggerakan seseorang untuk membaca dengan kemauannya sendiri.
Hasil survey UNESCO tahun 2011 menunjukkan bahwa minat baca bangsa Indonesia adalah paling rendah dibandingkan dengan negara- negara di kawasan Asia Tenggara. Ditemukan bahwa indeks membaca masyarakat Indonesia mencapai 0,001, yang berarti dari 1000 orang Indonesia, 1 orang yang memiliki minat membaca. Mengutip isi Human Development Report (HDR) tahun 1990 pada website Badan Pusat Statistik Kabupaten Sumedang (2014), pembangunan manusia adalah suatu proses untuk memperbanyak pilihan-pilihan yang dimiliki oleh manusia. Diantara banyak pilihan tersebut, pilihan yang terpenting adalah untuk berumur panjang dan sehat, untuk berilmu pengetahuan, dan untuk mempunyai akses terhadap sumber daya yang dibutuhkan agar dapat hidup secara layak. Untuk menjawab tantangantantangan mengenai isu literasi yang berkembang di Sumedang, sekelompok pemuda menjadi inisiator penggerak hidupnya kembali literasi dan berusaha memahamkan masyarakat untuk 


\section{Info Bibliotheca}

Jurnal Perpustakaan dan Ilmu Informasi

107

Published by Program Studi Perpustakaan dan Ilmu Informasi

FBS Universitas Negeri Padang, Indonesia

menjadikan literasi sebagai suatu kebutuhan dalam meningkatkan kesejahteraan. Salah satu gerakannya yaitu menyebarkan budaya membaca dan mengajak menyebarkan kebiasaan membaca. Adanya peran serta masyarakat untuk bergerak meski tidak secara langsung digerakkan oleh pemerintah menjadi potensi besar bagi warga Sumedang untuk terus berkembang ke arah yang lebih baik melalui gerakan masyarakat berbasis literasi. Dengan adanya Forum Literasi di Sumedang yang bergerak, kegiatan literasi dimulai dari lingkup-lingkup terkecil. Pola kegiatan literasi

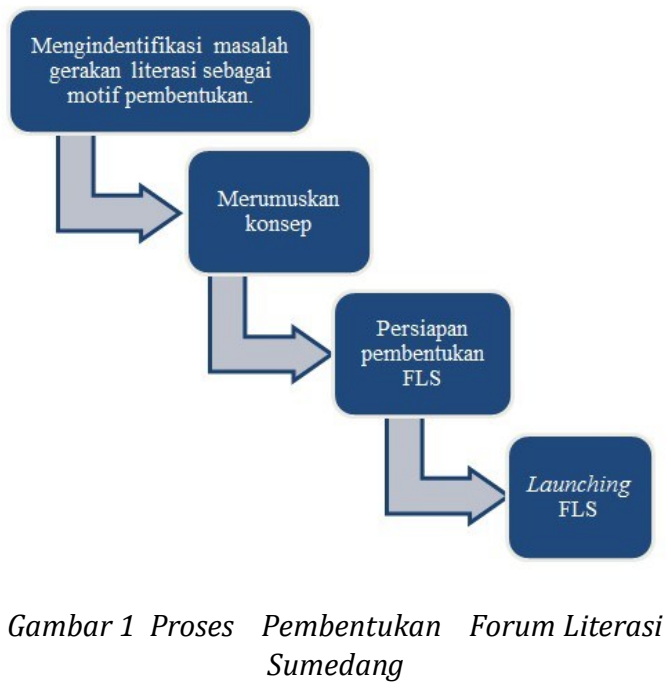

Mengindentifikasi masalah berdasarkan kemungkinan deprivasi fraternalistik yang dalam hal ini, permasalahan dari kondisi gerakan pegiat literasi itu sendiri. Tahap pembentukan Forum Literasi Sumedang, ini menjadi gambaran tentang kondisi Sumedang yang sedang menumbuhkan kembali gerakan literasi. Berkaca pada gerakan literasi di kota lain yang sudah menerapkan konsep kolaborasi dengan keterbukaan komunikasi antara pihak pemerintah dengan pegiat literasi terkait program literasi yang memungkinkan untuk dinergikan agar gerakannya lebih booming dan menarik perhatian banyak orang. Setelah mengintifikasi masalah selanjutnya adalah merumuskan konsep Forum Literasi Sumedang sebagai berikut: 


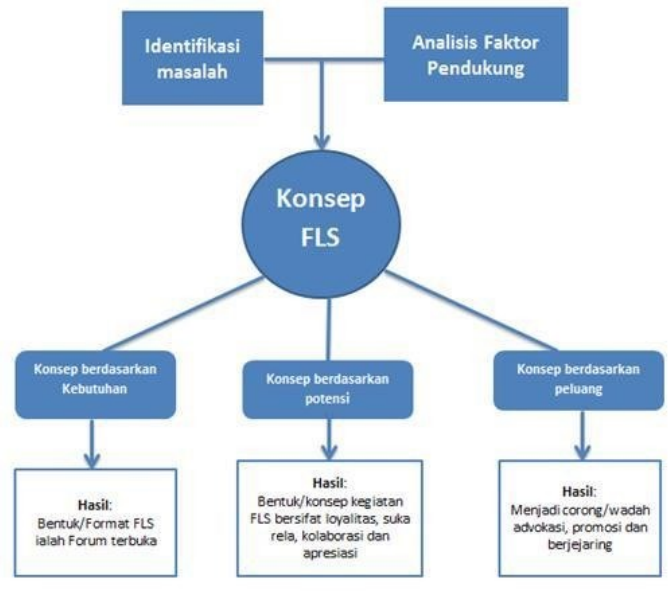

Berdasarkan bagan diatas, berikut penjelasan terkait dengan komponen yang menjadi landasan konsep Forum Literasi Sumedang:

$$
\text { Konsep pertama FLS }
$$

berdasarkan kebutuhan adalah dengan menjadikan FLS sebagai wadah terjadinya perkembangan gerakan literasi. Sebagaimana defini Forum yang telah dijelaskan pada bab 2, yaitu menurut Kamu Besar Bahasa Indonesia (KBBI), forum adalah sebuah lembaga atau badan; bisa juga diartikan sebagai wadah atau tempat pertemuan untuk bertukar pikiran secara bebas.

Konsep FLS yang kedua adalah konsep FLS berdarkan potensi-potensi yang ada pada gerakan literasi di
Sumedang adalah menggabungkan tiga faktor pendukungnnya menjadi sebuah dasar dari setiap rencana kegiatan FLS. Tiga faktor pendukungnya yaitu komitmen, aksi, dan apresiasi. Konsep kegiatan FLS didasari ketiga faktor tersebut. Setiap gerakan yang bersumber dari FLS maupun Komunitas yang melibatkan FLS menggunakan dasar komitmen mereka bergabung di FLS, kemudian diwujudkan menjadi aksi-aksi kolaborasi, semua terlibat, mengetahui informasinya, dan terakhir saling mengapresiasi.

Komponen terakhir dalam mengonsep FLS adalah analisis peluang. Peluang sama artinya dengan kesempatan. Berdasarkan faktor pendukung terbentuknya literasi, terdapat faktor yang diindikasi sebagai peluang, yaitu adanya respons positif dari berbagai pihak dan mendukun dibentuknya FLS. Sebelum dibentuk FLS, telah banyak aksi-aksi literasi yang dijalankan oleh beberapa orang atau komunitas. Namun belum saling terhubung. FLS dibentuk untuk 
Published by Program Studi Perpustakaan dan Ilmu Informasi FBS Universitas Negeri Padang, Indonesia

mewadahi aksi individu menjadi aksi kolektif. Wacana dibentuknya FLS mengundang respons positif dari para pegiat literasi, maupun dari komunitaskomunitas lain yang ada di Sumedang.

Berikut ini merupakan aktivitas literasi yang diselenggarakan oleh gabungan pegiat literasi pada Forum Literasi Sumedang:

a. Literasa; Literasi Remaja Sumedang (LITERASA) merupakan gebrakan perdana Forum Literasi Sumedang. Literasa merupakan aktivitas gerakan literasi yang menggabungkan para pegiat literasi untuk berada disatu kepanitiaan.

b. Pelatihan kepenulisan; Pelatihan kepenulisan ini merupakan program internal anggota Forum Literasi Sumedang.

c. Bincang-bincang literasi; Bincang-bincang literasi merupakan program talkshow mengenai literasi di Kabupaten Sumedang. d. Book Club; Book Club dimaksudkan untuk kelompok pecintah buku dan membaca. Kegiatannya berupa sharing isi buku non fiksi yang selama ini mengubah cara pandang kita terhadap dunia. Dengan kegiatan diskusi dari isi buku yang dibaca, peserta dapat mengetahui inti dari buku yang dibaca peserta lain, dan timbul ketertarikan untuk membaca buku yang diceritakan.

e. Pembentukan FTMB (Forum Taman Baca) di Kabupaten Sumedang karena jalur FTBM itu ada dibawah Kementrian Pendidikan dan Kebudayaan (Kemendikbud) bagian Direktorat Jenderal Pendidikan Anak Usia Dini dan Pendidikan Masyarakat. Hanya saja, pengurusnya hanya terdiri dari pengelola TBM-TBM yang ada dibawah PKBM atau TBM yang telah memiliki legalitas. 
Sedangkan TBM yang baru mulai merintis, atau bisa disebut TBM mandiri, yaitu TBM yang tidak mendapatkan pendanaan dari Kemendikbud, tidak terangkul untuk berkembang.

Pada kenyataannya, dibentuk FTBM Sumedang yaitu setelah adanya Forum Literasi Sumedang. Para pegiat literasi di Forum Literasi Sumedang yang memiliki taman baca, saling bertemu dan merumuskan kembali adanya forum taman baca di Sumedang. Pola aktivitas yang terjadi adalah pertama FLS menjadi center atau pusat gerakan. Dan yang kedua, FLS menjadi support system (sistem pendukung) gerakan literasi yang diselenggarakan oleh individu/ kelompok pegiat literasi pada Forum Literasi Sumedang

Berikut penjelasan mengenai pola aktivitas gerakan literasi pada Forum Literasi Sumedang:

a. Pola 1: FLS sebagai Center atau Pusat Gerakan
Pada pola ini, FLS diartikan sebagai aksi kolektif dari elemen-elemen pegiat literasi yang bergabung dengan FLS. Ide gerakan muncul dari inisiaor atau formatur FLS. Gerakan yang dilaksanakan bersifat sukarela. Pegiat literasi yang tergabung di Forum Literasi Sumedang menyumbangkan apapun baik barupa tenaga, fasilitas, ide dan lain-lain yang dibutuhkan untuk kegiatan.

b. Pola 2: FLS sebagai support system (Sistem Pendukung) Pada pola kedua, FLS berperan sebagai sistem pendukung (support system) terhadap aktivitas gerakan literasi yang diselenggarakan oleh salah satu komunitas/taman baca/lembaga yang termasuk di dalam Forum Literasi. FLS dalam hal ini adalah mereka yang menjadi anggota Forum Literasi Sumedang yang ikut membantu menyukseskan 
berbagai kegiatan literasi.

Bahkan ada yang mengambil

peran sebagai penyelenggara

kegiatan.

Pustakawan memiliki peran untuk menjaga eksistensi dan mengembangkan ilmu kepustakawanan, yang mencakup ilmu perpustakaan, dokumentasi, dan informasi (pusdokinfo). Implementasi terhadap peran tersebut tentunya harus dikoordinasikan dengan baik oleh pustakawan, khususnya dengan rekan sejawat dan pimpinan perpustakaan dan umumnya dengan pembuat kebijakan. Pustakawan harus menjalin komunikasi dan kerjasama yang solid dengan siapapun yang memiliki tujuan mencerdaskan anak bangsa melalui program pembudayaan literasi. Sebagai bahan evaluasi diri, pustakawan harus ingat bahwa "sebelum meliterasikan masyarakat, pustakawan harus literer terlebih dahulu". Bagi pustakawan, literasi tidak hanya terbatas pada literasi informasi biasanya dikaitkan dengan budaya baca dan tulis), tetapi juga literasi dalam pemanfaatan teknologi informasi dan komunikasi.

Dengan bekal literasi informasi dan TIK inilah pustakawan akan mampu memenuhi segala kebutuhan informasi pemustaka atau masyarakat sesuai dengan tupoksinya masingmasing.

Perwujudan dari harapan masyarakat ini dapat berupa tindakan (action) nyata dari pustakawan sebagai pejuang literasi. Dalam bertindak, pustakawan harus siap mental dan menguasai kompetensi tertentu agar nantinya dapat bekerja secara profesional dan tidak mengecewakan orang lain yang dilayaninya. Kini sudah saatnya pustakawan "unjuk gigi" dan aktif untuk meningkatkan literasi masyarakat melalui program- program literasi perpustakaan yang tepat guna dan tepat sasaran. Pustakawan harus peka terhadap isu- isu kepustakawanan yang sedang terjadi dan responsif terhadap kebutuhan informasi pengguna. Keberhasilan program literasi di masyarakat ini sangat tergantung pada "kepiawaian" 
107

Published by Program Studi Perpustakaan dan Ilmu Informasi

FBS Universitas Negeri Padang, Indonesia

pustakawan untuk menarik simpati dan empati masyarakat. Misalnya saja dalam program literasi pengembangan minat baca dan tulis masyarakat dalam acara sosialisasi, pustakawan sebagai narasumber atau pembicara dapat mencurahkan segala ide, gagasan, dan pemikirannya yang inovatif untuk merangsangmasyarakat untuk gemar membaca dan menulis. Agar program literasi yang dilaksanakan pustakawan berhasil dan mendapatkan dukungan dari segala pihak, maka perlu berkoordinasi dan menjalin komunikasi dengan baik kepada rekan kerja dan pimpinan lembaga. Sikap pustakawan yang telah berbicara di depan publik terkait dengan program-program inovasinya dapat dikatakan bahwa "mental" pustakawan telah teruji nyata, dan hal tersebut mendukung perwujudan program "revolusi mental" yang diusung oleh Presiden RI (Joko Widodo) melalui kontribusi nyata pustakawan dan perpustakaan dalam mencerdaskan anak bangsa. Wakil Ketua DPR RI (Fahri Hamzah), saat menerima audiensi dengan tiga organisasi kepustakawanan di
Indonesia, yaitu Asosiasi Penyelenggara Pendidikan Tinggi Ilmu Perpustakaan Indonesia (APTIPI), Ikatan Sarjana Ilmu Perpustakaan dan Informasi Indonesia (ISIPII), dan Forum Perpustakaan Perguruan Tinggi Indonesia (FPPTI) di Gedung DPR RI, Senayan, Jakarta, Selasa, 12 April 2016, mengatakan bahwa: "tidak ada revolusi mental tanpa perpustakaan". Kita (pemerintah) perlu mencanangkan "Gerakan Kembali ke Perpustakaan". Perpustakaan itu penting bagi sebuah bangsa, untuk menjaga sejarah bangsa, menjaga memori kolektif sebuah bangsa. Akan menjadi masalah besar, jika perpustakaan dan pustakawan tidak mau mengelola memori bangsa. Indonesia (negara ini) akan kekurangan imajinasi karena maraknya informasi yang instan "semuanya minus baca, kita hanya membaca teks pendek, 140 karakter, imajinasi bangsapun pendek, akhirnya gosip lebih melimpah dibanding dengan tulisan- tulisan yang memiliki bukti ilmiah". Lalu, dengan adanya Undang-undang Desa Nomor 6 Tahun 2014, di mana desa dialokasikan dana hingga 1,5 miliar Rupiah per 
tahun, ia juga ingin sebuah desa-pun harus punya perpustakaan, punya pustakawan desa, dan bahkan punya sejarawan desa (jika perlu). Pustakawan perlu mengkampanyekan bahwa perpustakaan adalah tempat yang nyaman bagi masyarakat hingga ke desa-desa (ISIPII, 2016).

Selain menguatkan mental, pustakawan juga perlu menerapkan strategi dan upaya untuk memenuhi kebutuhan informasi masyarakat atau pengguna yang semakin kompleks. Upaya awal yang dapat dilakukan adalah dengan mengkaji dan mengidentifikasi berbagai permasalahan yang dihadapi pengguna ketika meminta jasa ke pustakawan atau perpustakaan.

Pustakawan dapat mengkaji dan mengidentifikasinya melalui profil pengguna, perilaku pengguna, atau aspek lain yang terkait dengan kehidupan sosial pengguna. Hasil identifikasi tersebut kemudian manjadi bahan evaluasi dan solusi untuk membantu pemenuhan kebutuhan informasi pengguna. Selain itu, pustakawan juga dapat menetapkan "rencana prioritas" untuk pemanfaatan sumber daya perpustakaan yang sesuai dengan kebutuhan potensial pengguna. Sikap mental pustakawan dan terpenuhinya kebutuhan informasi pengguna ini menjadi dasar perwujudan harapan pustakawan. Hal yang diingat bahwa "harapan pustakawan tidak dapat tercapai jika harapan pengguna (yang dilayaninya) tidak tercapai, dan sebaliknya; harapan inilah yang diwujudkan dalam kemanfaatan pustakawan bagi masyarakat".

Terkait dengan perwujudan citacita, pustakawan harus "fokus dan konsentrasi". Fokus bukan berarti pustakawan tidak dapat menjadi seorang yang multitasking, tetapi fokus diperlukan agar program- program yang dilaksanakan pustakawan hasilnya maksimal. Konsentrasi terhadap satu tujuan program literasi hasilnya akan lebih baik jika dibandingkan dengan "nyambi" atau disertai mengerjakan hal lain. Kefokusan dan konsentrasi terhadap suatu aktivitas atau program yang sedang atau akan dilaksanakan pustakawan juga harus terukur dan 
dapat dilakukan (mampu). Terukur yang dimaksud disini adalah jelas target dan sasarannya; hasilnya dapat dihitung secara kuantitas dan kualitas. Misalnya, sebelum menetapkan program literasi masyarakat, pustakawan harus menghitung segala kebutuhan kegiatan dan mematangkan sumber daya organisasinya demi kelancaran dan kesuksesan program yang dilaksanakan, baik mencakup aspek kompetensi SDM, saranaprasarana, kebijakan, maupun anggaran kegiatan.

Untuk mewujudkan masyarakat literer ini, pustakawan dapat berperan dan berkontribusi nyata dalam mencerdaskan kehidupan bangsa melalui program-program literasi yang telah direncanakannya. Berikut ini peran dan kontribusi nyata pustakawan dalam mencerdaskan anak bangsa yang dapat dilakukan sesuai dengan latar belakang penulis sebagai pustakawan perpustakaan umum kabupaten Sumedang.

PENUTUP

\section{Simpulan}

Perpustakaan sebagai institusi yang berfungsi sebagai wahana pendidikan, penelitian, pelestarian, informasi, dan rekreasi seperti yang diamanahkan oleh Undang- Undang Nomor 43 Tahun 2007 tentang Perpustakaan, harus mempelopori gerakan literasi yang massif yakni gerakan membaca dan menulis yang diimbangi dengan membangun kerangka berpikir kritis dan logis sehingga akan menumbuhkembangkan budaya literasi pada masyarakat umumnya dan pemustaka pada khususnya. Di Kabupaten Sumedang, gerakan literasi mulai diperhatikan kembali mengikuti isu gerakan literasi yang berkembang di Nasional dari Kementerian Pendidikan daKebudayaan (Kemendikbud) sejak 2016. Dengan hadirnya beberapa komunitas penggiat dan peduli akan literasi di Sumedang yang terhimpun dalam sebuah Forum Literasi Sumedang menjadi titik awal bangkitnya kembali literasi di Kabupaten Sumedang. Untuk menjawab tantangan- tantangan mengenai isu literasi yang berkembang di Sumedang, 
Published by Program Studi Perpustakaan dan Ilmu Informasi FBS Universitas Negeri Padang, Indonesia

\begin{abstract}
sekelompok pemuda menjadi inisiator penggerak hidupnya kembali literasi dan berusaha memahamkan masyarakat untuk menjadikan literasi sebagai suatu kebutuhan dalam meningkatkan kesejahteraan. Dengan adanya
\end{abstract} Forum Literasi di Sumedang yang bergerak, kegiatan literasi dimulai dari lingkup-lingkup terkecil. Pola kegiatan literasi yang diselenggarakan oleh Forum Literasi Sumedang (FLS) melalui penyebaran informasi kegiatan literasi. Berkaca pada gerakan literasi di kota lain yang sudah menerapkan konsep kolaborasi dengan keterbukaan komunikasi antara pihak pemerintah dengan pegiat literasi terkait program literasi yang memungkinkan untuk dinergikan agar gerakannya lebih booming dan menarik perhatian banyak orang. Berdasarkan bagan diatas, berikut penjelasan terkait dengan komponen yang menjadi landasan konsep Forum Literasi Sumedang: Konsep pertama FLS berdasarkan kebutuhan adalah dengan menjadikan FLS sebagai wadah terjadinya perkembangan gerakan literasi. Konsep FLS yang kedua adalah konsep FLS berdarkan potensipotensi yang ada pada gerakan literasi di Sumedang adalah menggabungkan tiga faktor pendukungnnya menjadi sebuah dasar dari setiap rencana kegiatan FLS. Berikut ini merupakan aktivitas literasi yang diselenggarakan oleh gabungan pegiat literasi pada Forum Literasi Sumedang: a. Literasa; Literasi Remaja Sumedang (LITERASA) merupakan gebrakan perdana Forum Literasi Sumedang. Dengan kegiatan diskusi dari isi buku yang dibaca, peserta dapat mengetahui inti dari buku yang dibaca peserta lain, dan timbul ketertarikan untuk membaca buku yang diceritakan. Para pegiat literasi di Forum Literasi Sumedang yang memiliki taman baca, saling bertemu dan merumuskan kembali adanya forum taman baca di Sumedang. Dan yang kedua, FLS menjadi support system (sistem pendukung) gerakan literasi yang diselenggarakan oleh individu/ kelompok pegiat literasi pada 
107

Published by Program Studi Perpustakaan dan Ilmu Informasi

FBS Universitas Negeri Padang, Indonesia

Forum Literasi Sumedang Berikut penjelasan mengenai pola aktivitas gerakan literasi pada Forum Literasi Sumedang: a. Pola 1: FLS sebagai Center atau Pusat Gerakan Pada pola ini, FLS diartikan sebagai aksi kolektif dari elemen-elemen pegiat literasi yang bergabung dengan FLS. Pegiat literasi yang tergabung di Forum Literasi Sumedang menyumbangkan apapun baik barupa tenaga, fasilitas, ide dan lain-lain yang dibutuhkan untuk kegiatan. b. Pola 2: FLS sebagai support system (Sistem Pendukung) Pada pola kedua, FLS berperan sebagai sistem pendukung (support system) terhadap aktivitas gerakan literasi yang diselenggarakan oleh salah satu komunitas/taman baca/lembaga yang termasuk di dalam Forum Literasi. FLS dalam hal ini adalah mereka yang menjadi anggota Forum Literasi Sumedang yang ikut membantu menyukseskan berbagai kegiatan literasi. Pustakawan harus menjalin komunikasi dan kerjasama yang solid dengan siapapun yang memiliki tujuan mencerdaskan anak bangsa melalui program pembudayaan literasi. Bagi pustakawan, literasi tidak hanya terbatas pada literasi informasi (yang biasanya dikaitkan dengan budaya baca dan tulis), tetapi juga literasi dalam pemanfaatan teknologi informasi dan komunikasi. Kini sudah saatnya pustakawan "unjuk gigi" dan aktif untuk meningkatkan literasi masyarakat melalui program- program literasi perpustakaan yang tepat guna dan tepat sasaran. Misalnya saja dalam program literasi pengembangan minat baca dan tulis masyarakat dalam acara sosialisasi, pustakawan sebagai narasumber atau pembicara dapat mencurahkan segala ide, gagasan, dan pemikirannya yang inovatif untuk merangsangmasyarakat untuk gemar membaca dan menulis. Agar program literasi yang dilaksanakan pustakawan berhasil dan mendapatkan dukungan dari segala pihak, maka perlu berkoordinasi dan menjalin komunikasi dengan baik kepada rekan kerja dan pimpinan lembaga. Sikap pustakawan yang telah berbicara di depan publik terkait dengan program- 


\section{Info Bibliotheca}

Jurnal Perpustakaan dan Ilmu Informasi

ISSN 2714-805X

Volume 3 Nomor 12021

Page : 82-

107

Published by Program Studi Perpustakaan dan Ilmu Informasi

FBS Universitas Negeri Padang, Indonesia

program inovasinya dapat dikatakan bahwa "mental" pustakawan telah teruji nyata, dan hal tersebut mendukung perwujudan program "revolusi mental" yang diusung oleh Presiden RI (Joko Widodo) melalui kontribusi nyata pustakawan dan perpustakaan dalam mencerdaskan anak bangsa. Hal yang diingat bahwa "harapan pustakawan tidak dapat tercapai jika harapan pengguna (yang dilayaninya) tidak tercapai, dan sebaliknya; harapan inilah yang diwujudkan dalam kemanfaatan pustakawan bagi masyarakat".

\section{DAFTAR PUSTAKA}

Abidin, Y. (2015). Pembelajaran Multiterasi: Sebuah Jawaban atas Tantangan Pendidikan Abad Ke-21 dalam Konteks Keindonesiaan. Bandung: Refika Aditama Al Qurtuby, S. (2017). Meningkatkan Budaya Baca dan Literasi Masyarakat Indonesia. Diakses pada www. liputan6.com tanggal 10 Maret 2018 Alamsyah, R. 2017. Berita Peluncuran Forum Literasi Sumedang. http://inimahsumedang.com/f orumliterasi-sumedang- pembangunanmanusia- melalui-literasi/ diakses pada 29 Mei 2017. BPS Kabupaten Sumedang. 2014. Isi Human Development Report (HDR) tahun BPS. 2016. Persentase Penduduk Buta Huruf menurut Kelompok Umur, 2011-2016. https://www.bps.go.id/linkTa bleDinamis/view/id/1056 diakses pada 12 Juni 2017. BPS. 2015. Angka Melek Huruf Tahun 1996-2013 di Kabupaten Sumedang. https://jabar.bps.go.id/staticta ble/2015/09/23/76/angka-melekhuruf-per- kabupaten- kota-diprovinsi-jawa-barat-2004-2013.html Diakses pada 24 Desember 2017. Gumilar, R. (2018, April 8). Sumber Informasi Utama Profil dan Pembentukan Forum Literasi serta menggambarkan literasi di Kabupaten Sumedang (A. Dewi, Pewawancara) http://literasi.jabarprov.go.id/bacaartikel-954-apa-sih-literasi- itu.html diakses pada 23 Desember 2017. Hermawan, R \& Zen, Z. (2006). Etika 
107

Published by Program Studi Perpustakaan dan Ilmu Informasi

FBS Universitas Negeri Padang, Indonesia

Kepustakawanan: Suatu Pendekatan

Kencana Prenadamedia Group

Terhadap Kode Etik Pustakawan

Setiawan, I.A. (2018). Kupas Tuntas

Indonesia. Jakarta: Sagung Seto

Jenis dan Pengertian Literasi. Diakses

Rohanda, Tine S. R. dan Yunus W. 2018.

melalui https://gurudigital.id/jenis-

Budaya Literasi Masyarakat dan

pengertian-literasi pada 28 Maret 2018

Layanan Rosa, E.(2017). Peran

Sumekar, Sri. (2016). Sosialisasi

Perpustakaan Berbasis Budaya

Sustainable Development Goals (SDGs)

Literasi dalam pembangun Pondasi

Implementasi di Perpustakaan. Paparan

Bangsa. Diakses melalui

http://www.triniharyanti.id/2014/02/

membangun-budaya-literasi pada

Sosialisasi SDGs implementasi di

Perpustakaan, Gedung Teater

tanggal 29 Maret Setiadi, E.M. (2013).

Perpusnas, 1 Desember 2016 Sutarna,

Ilmu Sosial Budaya Dasar. Jakarta:

NS. (2006). Perpustakaan dan

masyarakat.Jakarta:Sagung Seto. 